\title{
Bone turnover biomarkers in obese postmenopausal Saudi women with
}

type-II diabetes mellitus

Nada M. Alselami' ${ }^{1}$, Amani F. H. Noureldeen ${ }^{1,2}$, Maryam A. AL-Ghamdi' Jalaluddin A. khan', Said S. Moselhy ${ }^{1,2}$

1. Biochemistry department, Faculty of science, King Abdulaziz University, Jeddah, KSA.

2. Biochemistry department, Faculty of science, Ain Shams University, Cairo, Egypt.

\section{Abstract}

Background: There is a high prevalence of diabetes mellitus type-2 (T2DM) and osteoporosis are problems worldwide. In this study, we evaluated the correlation between T2DM and bone turnover in diabetic obese postmenopausal Saudi women. Subjects and Methods: The present study included total of 65 T2-DM obese postmenopausal Saudi women, 36 unconSubjects and Methods: The present study included total of 65 T2-DM obese postmenopausal Saudi women, ( 36 uncon-
trolled, 29 controlled). The following serum biochemical parameters were evaluated [fasting blood glucose (FBG),total calcium (Ca), phosphorus (Pi), parathyroid hormone (PTH), 1,25-(OH)2Vitamin D3 , osteocalcin (OC), procollagen (PICP) and cathepsin $\mathrm{k}(\mathrm{Cath} \mathrm{K})]$.

Results: Serum OC levels were significantly decreased in diabetic obese postmenopausal group compared to their respective healthy group $(\mathrm{P}<0.004)$. PICP and Cath $\mathrm{K}$ were significantly elevated in diabetic postmenopausal group compared to the healthy group $(\mathrm{P}<0.024 \& 0.001)$. A significant elevation in 1,25(OH)2 Vitamin $\mathrm{D} 3, \mathrm{Ca}$ and Pi levels in diabetic obese postmenopausal patients group compared to the healthy group. However, a non-significant changes was observed in serum PTH level between different groups.

Conclusion: In this study, the changes in the biochemical parameters and bone turnover markers in obese women are strong risk factors for diabetes development that may contribute to osteopenia and osteoporosis. The study showed the strong effect of T2DM on biochemical markers of bone turnover in obese postmenopausal Saudi women.

Keyword: Diabetes mellitus type-2, Bone markers, Postmenopausal

DOI: http://dx.doi.org/10.4314/ahs.v15i1.12

\section{Introduction}

Type-2 diabetes mellitus (T2DM) is a worldwide pandemic and World Health Organization (WHO) predicts that the current figure of 170 million affected patients with diabetes will be more than double, to 370 million patients by the year $2030^{1}$. Saudi Arabia is currently at the top of the list in the middle east countries with the highest number of estimated cases of diabetes mellitus $^{2}$. Multiple factors affected the lifestyle of Saudi Arabian population whith more tendence to western life style. The population of Saudi Arabia with changes in lifestyle, reduction of physical activity and high calorie snacks and foods have led to increased prevalence of

\section{Corresponding author:}

Said S Moselhy,

Biochemistry Department, Faculty of Science,

King Abdulaziz University.

Email; moselhy6@hotmail.com

Tel:00966566991424 this point bone resorption and formation are equally balanced. Levels of peak bone mass are strongly influenced by genetic factors although diet and exercise also play a role ${ }^{7}$. Bone remodeling can be divided into the following phases: quiescent, activation, resorption, formation, mineralization ${ }^{8}$.

Sharifi et $\mathrm{al}^{9}$ found that a higher level of HbA1c, a marker of blood glucose control, was related to lower lumbar spine density in diabetic women?.

The goal of the present study to evaluate the impact of type-II diabetes mellitus on biochemical markers of bone turnover in obese postmenopausal Saudi women. This work is a trail to set up measurements for some bone turnover markers in both obese postmenopausal female with type-II diabetes mellitus and normal subject

\section{Subjects and Method}

\section{Subjects}

Sixty five postmenopausal Saudi women with type 2 diabetes mellitus (36 uncontrolled, 29 controlled) aged between (45-57士4.32) years old were randomly selected from diabetic patients during their clinical visits to medical administration at king Abdul Aziz University, Jeddah, Saudi Arabia. In addition, twenty healthy apparent volunteer subjects matched age between 4757 years served as control (group I). Group П: Diabetic patients were divided into two subgroups depending on their glycosylated hemoglobin level (HbA1c): Controlled DM, they are regularly checked every three months in diabetic center at King Abdulaziz University hospital. The blood sample was withdrawn from patients every visit ( 3 month) to check the blood glucose control, also the glycosylated hemoglobin (HbA1c) was measured in each blood sample for 3 consecutive samples and uncontrolled DM subgroup: Included 36 postmenopausal diabetic patients.

\section{Methods:}

The biochemical parameters in the serum [fasting blood glucose (FBG), calcium $(\mathrm{Ca})$, phosphorus $(\mathrm{Pi})$, parathyroid hormone (PTH), 1,25-(OH)2Vit.D3 ,osteocalcin (OC), procollagen (PICP) and cathepsin k (Cath K) ] were evaluated using kits from Biodiagnostic ,England. Statistical Analysis: Statistical analyses were performed with SPSS statistical software package (version, 15). Numerical data presented in the present study were expressed as mean value for each parameter \pm it's corresponding standard deviation of the mean. One way analysis of variance (ANOVA) was carried out to test the significance of difference between groups mean values for each parameter. For all comparisons, P-values of $<0.05$ were considered statistically significant. Correlation coefficient study " $r$ " was carried out to find out the relationships between parameters in the same group.

\section{Results}

Table (1) shows the (mean values \pm standard deviation of general characteristics for all the studied groups including: age, duration of diabetes, BMI, fasting blood glucose, glycosylated hemoglobin, systolic and diastolic blood pressure.

Analysis of data by ANOVA indicated a significant differences in mean values between groups for each of BMI, fasting blood glucose, glycosylated hemoglobin, systolic and diastolic blood pressure $(\mathrm{P}<0.001$ $0.0001,0.0001,0.032$ and 0.022 respectively).
Type 2-diabetes differs from type I (IDDM) which occurs in young age, there is absence of insulin and it treated only with insulin injection.

The structure of the mature adult skeleton is the result of different cellular mechanisms. These are endochondral and intramembranous ossification together with modeling and remodeling on preformed surfaces. The interplay of these mechanisms determines the form of the adult skeleton. Estrogen plays an important role in these mechanisms. In normal individuals, bone mass increases during skeletal growth to reach a peak at the beginning of the third decade and at 
Table 1: Mean values \pm SD of (age, duration of diabetes, BMI, FBG, HbA1c,

systolic and diastolic BP) in all the studied groups.

\begin{tabular}{|c|c|c|c|c|}
\hline \multirow[t]{2}{*}{\begin{tabular}{|c|} 
Group \\
Variables
\end{tabular}} & \multirow{2}{*}{$\begin{array}{l}\text { Healthy } \\
\text { control } \\
\mathbf{N}=20\end{array}$} & \multicolumn{2}{|c|}{$\begin{array}{l}\text { Diabetic } \\
\text { group }\end{array}$} & \multirow[t]{2}{*}{$P$-value } \\
\hline & & $\mathrm{DM}($ Controlled $) \mathrm{n}=29$ & $\mathrm{DM}($ Un-controlled) $\mathrm{n}=36$ & \\
\hline Age (Years) & $\begin{array}{l}51.30 \pm 4.318 \\
(45-60)\end{array}$ & $\begin{array}{c}50.00 \pm 2.493 \\
(45-54)\end{array}$ & $\begin{array}{l}50.00 \pm 2.493 \\
(45-54)\end{array}$ & 0.097 \\
\hline $\begin{array}{l}\text { Duration of } \\
\text { Diabetes (years) }\end{array}$ & ------- & $\begin{array}{c}5.45 \pm 0.948 \\
(4-7)\end{array}$ & $\begin{array}{c}5.39 \pm 1.536 \\
(3-10)\end{array}$ & N.S \\
\hline BMI (kg/m2) & $\begin{array}{r}29.36 \pm 2.186 \\
(25.60-31.90)\end{array}$ & $\begin{array}{c}28.38+3.365 \\
(25.1-36.20)\end{array}$ & $\begin{array}{c}30.81 \pm 2.006 \\
(27.60-34.60)\end{array}$ & 0.001 \\
\hline FBG $(\mathrm{mmo} / \mathrm{L})$ & $\begin{array}{c}4.00 \pm 0.355 \\
(3.24-4.51)\end{array}$ & $\begin{array}{l}5.63 \pm 0.622 \\
(4.59-6.83)\end{array}$ & $\begin{array}{l}11.20 \pm 4.958 \\
(4.44-27.57)\end{array}$ & 0.0001 \\
\hline HbA1c (\%) & $\begin{array}{l}5.13 \pm 0.539 \\
(4.41-5.8)\end{array}$ & $\begin{array}{r}5.43 \pm 0.327 \\
(4.73-6.11)\end{array}$ & $\begin{array}{l}9.19 \pm 2.076 \\
(6.2-13.6)\end{array}$ & 0.0001 \\
\hline $\begin{array}{l}\text { Systolic } \\
\text { BP } \\
\text { (mmHg) }\end{array}$ & $\begin{array}{c}114.30 \pm 15.458 \\
(90.00-140)\end{array}$ & $\begin{array}{c}132.76 \pm 30.579 \\
(90-190)\end{array}$ & $\begin{array}{l}130.47 \pm 24.924 \\
(90-180)\end{array}$ & 0.032 \\
\hline $\begin{array}{l}\text { Diastolic } \\
\text { BP (mmHg) }\end{array}$ & $\begin{array}{l}77.10 \pm 7.629 \\
(62-93)\end{array}$ & $\begin{array}{c}78.41 \pm 11.400 \\
(60-100)\end{array}$ & $\begin{array}{l}85.39 \pm 14.618 \\
(60-120)\end{array}$ & 0.022 \\
\hline
\end{tabular}

Results of ANOVA indicated significant differences be- Vitamin D3 ( $\mathrm{P}<0.024,0.0001$ and 0.007 respectively) tween groups in the value total $\mathrm{Ca}, \mathrm{Pi}$ and $1,25(\mathrm{OH}) 2$ No significant difference was detected between normal and diabetic groups for PTH (Table, 2).
Table 2. Mean values + SD of calcium homeostasis markers ( total calcium, phosphorus, parathyroid hormone and active vitamin $D_{3}$ ) in all the studied groups.

\begin{tabular}{|c|c|c|c|c|}
\hline \multirow{2}{*}{ Gariables } & \multirow{2}{*}{$\begin{array}{l}\text { Healthycontrol } \\
\quad \begin{array}{l}\mathbf{N}=2 \\
\mathbf{0}\end{array}\end{array}$} & \multicolumn{2}{|c|}{ Diabeticgroup } & \multirow[t]{2}{*}{$P$-value } \\
\hline & & DM(Controlled $)=29$ & $\mathrm{DM}($ Un-controlled $) \mathrm{n}=36$ & \\
\hline $\begin{array}{c}\mathbf{C a} \\
(\mathbf{m m o l} / \mathbf{L}) \\
\text { mean } \pm \text { SD } \\
\text { Range }\end{array}$ & $\begin{array}{l}2.54 \pm \\
0.229(1.86 \\
-2.88)\end{array}$ & $\begin{array}{l}2.77 \pm \\
0.391(1.32 \\
-3.49)\end{array}$ & $\begin{array}{l}2.62 \pm 0.237 \\
(2.28-3.23)\end{array}$ & 0.024 \\
\hline $\begin{array}{c}P_{i} \\
(\mathbf{m m o l} / L) \\
\text { mean } \pm \text { SD } \\
\text { Range }\end{array}$ & $\begin{array}{l}2.61 \pm \\
0.298(1.84 \\
-3.13)\end{array}$ & $\begin{array}{l}2.68 \pm 0.572 \\
(0.91-3.37)\end{array}$ & $\begin{array}{l}3.32 \pm 0.195 \\
(2.93-3.84)\end{array}$ & 0.0001 \\
\hline $\begin{array}{c}\text { PTH } \\
(\mathbf{p g} / \mathrm{ml}) \\
\text { mean } \pm \text { SD } \\
\text { Range }\end{array}$ & $\begin{array}{l}60.33 \pm 14.647 \\
(36.42-89.17)\end{array}$ & $\begin{array}{l}64.53 \pm \\
31.106(24.40 \\
-148.34)\end{array}$ & $\begin{array}{l}67.27 \pm 29.169 \\
(26.33- \\
133.62)\end{array}$ & N.S \\
\hline $\begin{array}{c}\text { 1,25(OH) })_{2} \text { vit.D } \\
3(\mathrm{Pmol} / \mathrm{L}) \\
\operatorname{mean} \pm \mathrm{SD} \\
\text { Range }\end{array}$ & $\begin{array}{l}122.85 \pm 40.368 \\
(60.85- \\
188.85)\end{array}$ & $\begin{array}{c}127.51 \pm 54.298 \\
(15.86-261.96)\end{array}$ & $\begin{array}{l}159.16 \pm \\
45.483(93.13- \\
238.37)\end{array}$ & 0.007 \\
\hline
\end{tabular}

Table (3) shows the mean values of bone formation terminal propeptide) and bone resorption marker markers (osteocalcin and procollagen type- $\alpha$ carboxy (cathepsin k)

Table 3. Mean values \pm SD of biochemical markers of bone

turnover including bone formation markers ( osteocalcin and

procollagen type- $\alpha$ carboxy terminal propeptide) and bone

resorption marker (cathepsin $k$ ) in

the studied groups.

\begin{tabular}{|c|c|c|c|c|}
\hline \multirow[t]{2}{*}{ Group } & \multirow[b]{2}{*}{$\begin{array}{c}\text { Normal } \\
\mathbf{N}=\mathbf{2 0}\end{array}$} & \multicolumn{2}{|c|}{ Diabetic groups } & \multirow{2}{*}{$P$-valuc } \\
\hline & & $\begin{array}{l}\text { controlled } \\
\mathrm{n}=29\end{array}$ & $\begin{array}{c}\begin{array}{c}\text { uncontrolled } \\
\mathrm{n}=36\end{array} \\
\text { (n) }\end{array}$ & \\
\hline$O C(\mathrm{ng} / \mathrm{ml})$ & $\begin{array}{c}18.34 \pm 5.571 \\
(11.86-28.75)\end{array}$ & $\begin{array}{l}14.59 \pm 3.981 \\
(7.40-21.92)\end{array}$ & $\begin{array}{r}12.74 \pm 4.187 \\
(5.81-23.87)\end{array}$ & 0.004 \\
\hline $\operatorname{PICP}(\mathrm{ng} / \mathrm{ml})$ & $\begin{array}{r}2.44 \pm 4.846 \\
(0.02-21.53) \\
\end{array}$ & $\begin{array}{r}5.59 \pm 11.451 \\
(0.02-58.38) \\
\end{array}$ & $\begin{array}{c}11.29 \pm 14.799 \\
(0.03-70.53) \\
\end{array}$ & 0.024 \\
\hline Cathk(pmol/L) & $\begin{array}{r}109.85 \pm 75.949 \\
(19.81-236.12)\end{array}$ & $\begin{array}{r}204.76 \pm 92.381 \\
(98.15-415.20)\end{array}$ & $\begin{array}{c}239.89 \pm 129.252 \\
(54.86-554.56)\end{array}$ & 0.0001 \\
\hline
\end{tabular}


Data obtained from ANOVA studies indicated signifi- $\mathrm{r}:-0.340$, P: 0.046). On other hand, correlation coeffi-

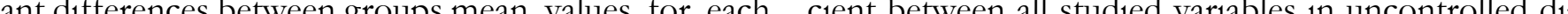
of OC, PICP and Cath $\mathrm{k} \quad(\mathrm{P}<0.004,0.025$, betic subgroup showed that blood glucose had a highly and 0.0001 , respectively). Correlation studies showed significant positive correlation with glycosylated hemothat serum cathepsin $\mathrm{k}$ showed a significant positive globin ( $\mathrm{r}: 0.696, \mathrm{P}: 0.0001)$.

correlation ( $r: 0.614$, P: 0.005) with procollagen in the

normal group. While, correlation studies in controlled Duncan multiple range " $\mathrm{r}$ " for testing the significan diabetic subgroup between blood pressure (systolic and difference between normal group and controlled didiastolic) with BMI showed a highly significant pos- abetic subgroup revealed no significant differitive correlation $(r: 0.680$, P: $0.0001 \& r: 0.588$, P: ence in phosphorus, parathyroid hormone and active 0.001). Diastolic blood pressure showed a significant form of vitamin D3. While, the mean value of calcium negative correlation with blood glucose ( $\mathrm{r}:-0.396, \mathrm{P}$ : was highly significant compared to normal group and correlation with glycosylated hemoglobin $(r: 0.415, \mathrm{P}:$ significant difference between normal group and un0.025). Procollagen type- $\alpha$ carbocxy terminal propep- controlled diabetic subgroup the data showed no signiftide showed a significant negative correlation with dias- icant difference in mean values of calcium and parathytolic blood pressure ( $\mathrm{r}$ : - 0.402, P: 0.031) and showed roid hormone. While, the mean value of phosphoru a significant positive with calcium ( $r$ : 0.374, P: 0.027 ) and active form of vitamin D3 was highly significan and a significant negative with parathyroid hormone ( between the normal group and uncontrolled diabetic subgroup (Tables $4-7$ )

Table 4. One way analysis of variance (ANOVA) for testing the significance of differences between groups mean values of total calcium.

\begin{tabular}{|c|c|c|}
\hline Groups & Controlled Diabetic & Uncontrolled diabetic \\
\hline Normal & $* *$ & N.S \\
\hline Controlled Diabetic & & N.S \\
\hline
\end{tabular}

N.S: non-significant

Table 5. One way analysis of variance (ANOVA) for testing the

significance of differences between groups mean values of phosphorus.

\begin{tabular}{|c|c|c|}
\hline Groups & Controlled Diabetic & Uncontrolled diabetic \\
\hline Normal & N.S & $* * *$ \\
\hline Controlled Diabetic & & $* * *$ \\
\hline
\end{tabular}

*** Highly Significant at $\mathrm{P}<0.001$

Table 6. One way analysis of variance (ANOVA) for testing the significance of differences between groups mean values of parathyroid hormone.

\begin{tabular}{|c|c|c|}
\hline Groups & Controlled Diabetic & Uncontrolled diabetic \\
\hline Normal & N.S & N.S \\
\hline Controlled Diabetic & & N.S \\
\hline
\end{tabular}

Table 7. One way analysis of variance (ANOVA) for testing the significance of differences between groups mean values of active form of vitamin $D$.

\begin{tabular}{|c|c|c|}
\hline Groups & Controlled Diabetic & Uncontrolled diabetic \\
\hline Normal & N.S & $* *$ \\
\hline Controlled Diabetic & & $* *$ \\
\hline
\end{tabular}

** Very Significant at $\mathrm{P}<0.01$

Discussion:

Status of vitamin D is very important in diabetic mellitus patients. Immense studies showed that both healthy and diabetic subjects had a seasonal variation of glycemic control. Currently, the evidence supporting that vitamin $\mathrm{D}$ level is important to regulate some pathways related to type 2 diabetes development ${ }^{10}$, due to vitamin $\mathrm{D}$ which is important for insulin synthesis and release. Since the activation of inflammatory pathways interferes with normal metabolism and disrupts proper insulin signaling, it is hypothesized that vitamin D could influence glucose homeostasis by modulating inflammatory response ${ }^{10}$. Type- $\Pi$ diabetes development involves impaired pancreatic $\beta$ - cell function, insulin resistance and inflammation. Although mechanistically unclear, it has been suggested that both environmental and genetic factors seem to be involved in developing type- $\Pi$ diabetes mellitus ${ }^{11,12}$. Moreover, it has been confirmed that vitamin $\mathrm{D}$ play an important role in insulin sensitivity by controlling calcium flux through the membrane in both $\beta$-cells and peripheral insulin target tissue ${ }^{13}$.

The results obtained showed a tendency for obesity (BMI $\geq 30$ ) among uncontrolled diabetic women and overweight (25- $29.9 \mathrm{Kg} / \mathrm{m} 2)$ among controlled diabetics and undiabetic control women. The study confirmed an inverse association between vitamin $\mathrm{D}$ level and anthropometric measures of body size in type- $\Pi$ diabetic patients. The reason for this is that the body weight and body fat are inversely correlated with $25(\mathrm{OH}) \mathrm{D}$ levels across the spectrum of body weight ranging from normal to obese $\mathrm{e}^{14}$. This inverse association is related to the greater volume of distribution for both vit-D and $25(\mathrm{OH}) \mathrm{D}$ in tissue. Vitamin D appears to affect exclusively the insulin response to glucose stimulation. The direct effect of vitamin $\mathrm{D}$ may be mediated by binding of its circulating active form, 1,25 (OH)2 D3 to the beta cell of vitamin $\mathrm{D}$ receptor $[1,25(\mathrm{OH}) 2 \mathrm{D} 3,159.16$
pmol/L ]. Vitamin D has a beneficial effect on insulin action either directly by stimulating the expression of insulin receptor thereby enhancing insulin responsiveness for glucose transport ${ }^{15}$, or indirectly via its role in regulating extracellular calcium ensuring normal calcium influx through cell membranes and adequate intracellular cytosolic calcium. However, the demonstration that $25(\mathrm{OH}) \mathrm{D}$ supplementation enhances insulin sensitivity and improves glucose homeostasis in type- $\Pi$ diabetes patients is considered a great clinical interest ${ }^{16}$. The result obtained in this study is that the higher level of $1,25(\mathrm{OH}) 2$ vitamin $\mathrm{D} 3$ in uncontrolled diabetic subjects $(159.16 \mathrm{pmol} / \mathrm{L})$ with highest level of PTH $(67.27$ $\mathrm{pg} / \mathrm{ml}$ ) in the same group could be the major and novel finding of this study as an independent predictor of metabolic syndrome (MS). This is because a previous study showed that metabolic syndrome (MS) was diagnosed in patients with at least 3 of the following characteristics (1) elevated fasting triglycerides, elevated blood pressure $(\geq 130 / 85)$ and elevated fasting glucose $(\geq$ $5.6 \mathrm{mmol} / \mathrm{L}$ ). The three characteristics are highly implicated to all our subjects beside the elevation of HbA1c and the phosphate $(3.32 \mathrm{mmol} / \mathrm{L})$. The result showed that postmenopausal women with normal serum calcium $(2.62 \pm 0.237 \mathrm{mmol} / \mathrm{L})$ but inappropriately high PTH, had higher serum glucose, glycosylated hemoglobin and BMI as well as with systolic and diastolic blood pressure.

The only bone resorption cathepsin $\mathrm{k}$ studied in this study project, showed highly significant increase (239.89 $\mathrm{pmol} / \mathrm{L}$ ) in uncontrolled patients with type-П diabetic compared with controlled diabetic subgroup (204.76 $\mathrm{pmol} / \mathrm{L})$ and healthy control women $(109.85 \mathrm{pmol} / \mathrm{L})$ This is indicated that bone resorption in postmenopausal Saudi women with type- $\Pi$ diabetes mellitus whethe controlled or uncontrolled are very high, which leads to 
high risk of fracture. The overall of results and findings in this study confirmed the high link between deficiency of vitamin $\mathrm{D}$ status, hyperparathyroidism and type- $\Pi$ diabetic specifically in obese postmenopausal women which could lead to metabolic syndrome which is cluster of risk factors including abdominal obesity, insulin resistance, dyslipidemia, hyperglycemia and elevated blood pressure, which were found in our patients ${ }^{17}$.

\section{Conclusion}

The present study has demonstrated that bone problems is highly prevalent among Saudi obese postmenopausal diabetic women. It seems obvious that further studies are needed to address the best preventive practical measures to overcome osteoporosis in obese postmenopausal Saudi women.

\section{Acknowledgement}

The authors would like to thank King Abdulaziz City for Science and Technology (KACST) for financial support this project under grand \# (AT-18-53) .

\section{References:}

1. World Health Organisation ,The Diabetes Program 2004. Available at: http//www.who.int/diabetes/en/. September 212004.

2. Wild S, Roglic G, Green A, et al. Global prevalence of diabetes:estimates for the year 2000 and projections for 2030. Diabetes Care. 2004;27:1047-53

3. Al-Nuaim AR - Population based epidemiological study of the prevalence of overweight and obesity in Saudi Arabia, regional variation. Ann Saudi Med. 1997; 17:195-9.

4. El-Hazmi MAF, Warsy AS - Prevalence of overweight and obesity in diabetic and non-diabetic Saudis. East Med Health J. 2000; 6:276-82.

5. El-Hazmi MA, Warsy AS - Obesity and overweight in Type II diabetes mellitus patients in Saudi Arabia. Saudi medical journal. 1999; 20:167-72.

6. Adami S. Bone health in diabetes: considerations for clinical management. Curr Med Res Opin. 2009;25(5):1057-72.
7. Lindsay R. and Kelly P. (1996) Osteoporosis in postmenopausal women. In "Clinical Management of the Menopause" (B. G. Wren and L. E. Nachtigall, eds.), McGraw-Hill, Sydney, Australia. pp. 86-105.

8. Compston, J.E. (2001) Sex steroids and bone, Physiol Rev, 81:419-47.

9. Sharifi F, Ahmadimoghadam N, Mousavinasab N, Amani R, Mostafavi A, Agin K, et al. The Relationship Between Type 2 Diabetes Mellitus And Bone Density In Postmenopausal Women. Int J Endocrinol Metab. 2006;4(3):117-22.

10. Andrade Chages, C.E.; Borges, M.C., Martini, L. A., and Rogero, M.M. Focus on vitamin D, inflammation and type-П Diabetes.2012; Nut.4: 52-67.

11. Wolden- kirk H.; Overbergh L., Christesen H. T., Brusgaard K. and Mathieu C. Vitamin D and Diabetes for beta cell and immune function. Mol Cell Endcr. 2011;347: 106- 20.

12. Pittar A. and Dawson-Hughes . Vitamin D and diabetes. J Sterol Biochem Mol Biol. 2010;121: 425-9.

13. Takiishi T.; Gysemans C., Bouillon R., and Mathieu C. Vitamin D and diabetes. Endocr Meta Clin. 2010; 39: 419-46.

14. Andjela T. Drincic,; Laura A.G., Armas Eileen E., Vandiest and Robert P. Heaney. Volumetric Dilution, Rather than Sequestration best explains the low vitamin D status of obesity. Obes. 2011;10:404.

15. Maestro B.; Campion J., Davila N., and Calle C. Stimulation by $1,25(\mathrm{OH}) 2 \mathrm{D} 3$ of insulin receptor expression and insulin responsiveness for glucose transport in U-937 human promonocytic cells. Endocr J. 2000;47: 383-91.

16. Kwame Osei , $25(\mathrm{OH})$ D:Is it the Universal Panacea for Metabolic syndrome and type 2 Diabetes? J Clin Endocr Metab. 2010;95(9): 4220-2.

17. Jorn Hjelmesaeh; Dag Hofso, Erlend T. Aasheim, Trond Jenssen, Johan Moan, Helle Hager, Jo Roislien and Jens Bollerslev. Parathyroid hormone, but not Vitamin D, is associated with the metabolic syndrome in morbidity obese women and men: a cross-sectional study cardiovascular Diabetology.2009; 8:7-14. 